\title{
Can We Restore the Marches in Iraq (Garden of Eden)?
}

\author{
Nadhir Al-Ansari \\ Department of Civil, Environmental and Natural Resources Engineering, Lulea University of Technology, Lulea, Sweden \\ Email:nadhir.alansari@ltu.se
}

How to cite this paper: Al-Ansari, N. (2020) Can We Restore the Marches in Iraq (Garden of Eden)? Engineering, 12, 466-486. https://doi.org/10.4236/eng.2020.127033

Received: July 4, 2020

Accepted: July 17, 2020

Published: July 20, 2020

Copyright (c) 2020 by author(s) and Scientific Research Publishing Inc. This work is licensed under the Creative Commons Attribution International License (CC BY 4.0).

http://creativecommons.org/licenses/by/4.0/

\begin{abstract}
Iraqi marshes are located within the southern part of Iraq where the Tigris and Euphrates Rivers join. There are three main marshes (Hammar Central and Hawizeh). They used to cover an area 15,000 - 20,000 square kilometers. The government of Iraq started to dry the marshes since 1990 for military reasons. Oil companies started to work in that area, and they occupied about $25 \%$ of that area. After 2003, the government changed, and they started to restore the remainder $75 \%$ of marshes. To achieve this goal, they require about 13 billion cubic kilometers of water (BCM). The problem was the scarcity of water due to the building of dams in riparian countries and climate change. It is believed that if the government follows a prudent water resources strategy, then it will be possible to restore the marshes.
\end{abstract}

\section{Keywords}

Mesopotamia, Marsh, Garden of Eden, Iraq

\section{Introduction}

The marshes in Iraq referred to as the "Garden of Eden" are located within the southern part of Iraq, which are created by the Tigris and Euphrates Rivers system (Figure 1). The area is characterized by its very tow slope where it ranges from 4 to $8 \mathrm{~cm} / \mathrm{km}$ within the Euphrates and Tigris respectively which caused the two rivers to split and meander. The area stretches between double deltas, the inner delta produced by Hillah-Hindiyah on the Euphrates and Sghatt alGharaf on the Tigris, and a marine delta created by the Karun and Marunjerrahi river system [1].

The area represents a unique ecosystem providing local inhabitants with an essential source of habitat and livelihoods, and it has played a vital role in the economic and social advancement of the people of Iraq. In addition, they 
represent national heritage and ecological area. The area was considered as the largest wetland in the world and the greatest in western Asia. Furthermore, it is considered one of the eleven non-marine wetland areas in the world with Endemic Bird Area status [2] [3] [4] [5]. This area was inhabited since the dawn of civilization about 6000 years BP (Figure 2 and Figure 3) [4] [5] [6] [7].

Sometimes the inhabitants of the area are called "Ma'dan" and they are supposed to be descendants of Sumerians. Most of the inhabitants are semi-nomadic; their settlements are located at the edges of the marshes or on artificial islands, their houses are usually built of reed and mud, and Water buffalos are very important for the Marsh Arabs existence (Figure 4 and Figure 5). The buffalos are fed on young reed shoots, and they provide them with milk, butter, yogurt, as well as energy and crop fertilizer in the form of fuel and manure. In addition,
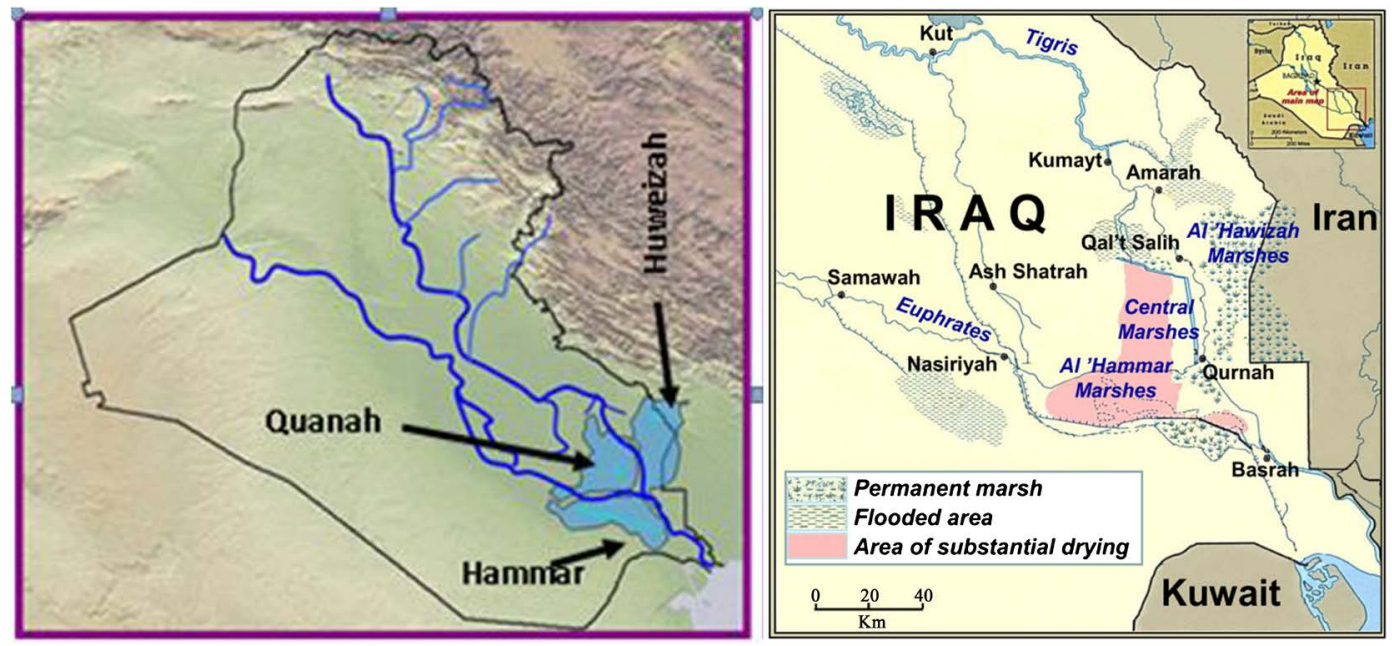

Figure 1. Maps of Iraqi marshes.
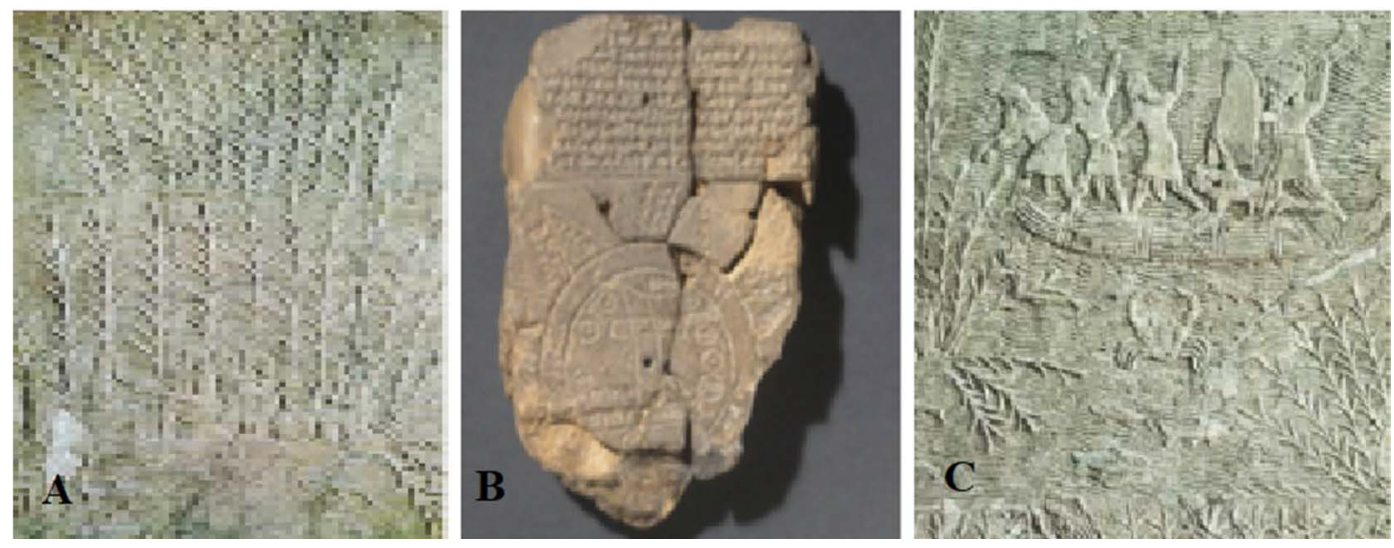

Figure 2. Some photos reflecting Sumerian life in the marshes [8]. (A) "He (Merodach-Baladan, King of Babylon) fled like a bird to the swampland" and "I (Sennacherib, King of Assyria) sent my warriors into the midst of the swamps ... and they searched for five days". But the King of Babylon could not be found. (703 B.C.) [9]. (B) Babylonian Clay Map. The world is shown as a circle surrounded by a "bitter river". The Euphrates flows south to a horizontal band marked "marsh" on the right and "outflow" on the left. British Museum collection. Photo courtesy of the British Museum. (C) Relief showing life in the marshlands in ancient times. 

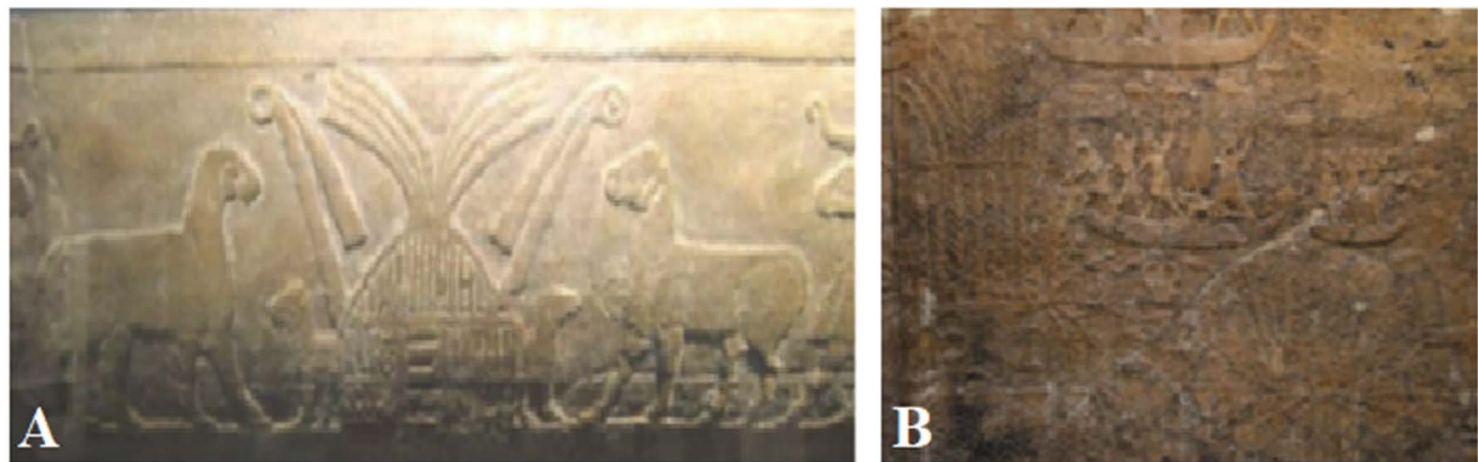

Figure 3. (A) Pictorial Representation of Sheep and a Reedhouse on a Through Found in Uruk. Collection of the Vorderasiatisches Museum, Berlin. By: Qahtan Al Abeed (B) Assyrian Relief from the Palace of Sennacherib in Niniveh: Fighting Scene in the Southern Marshes. British Museum collection. By: Qahtan Al Abeed [5].

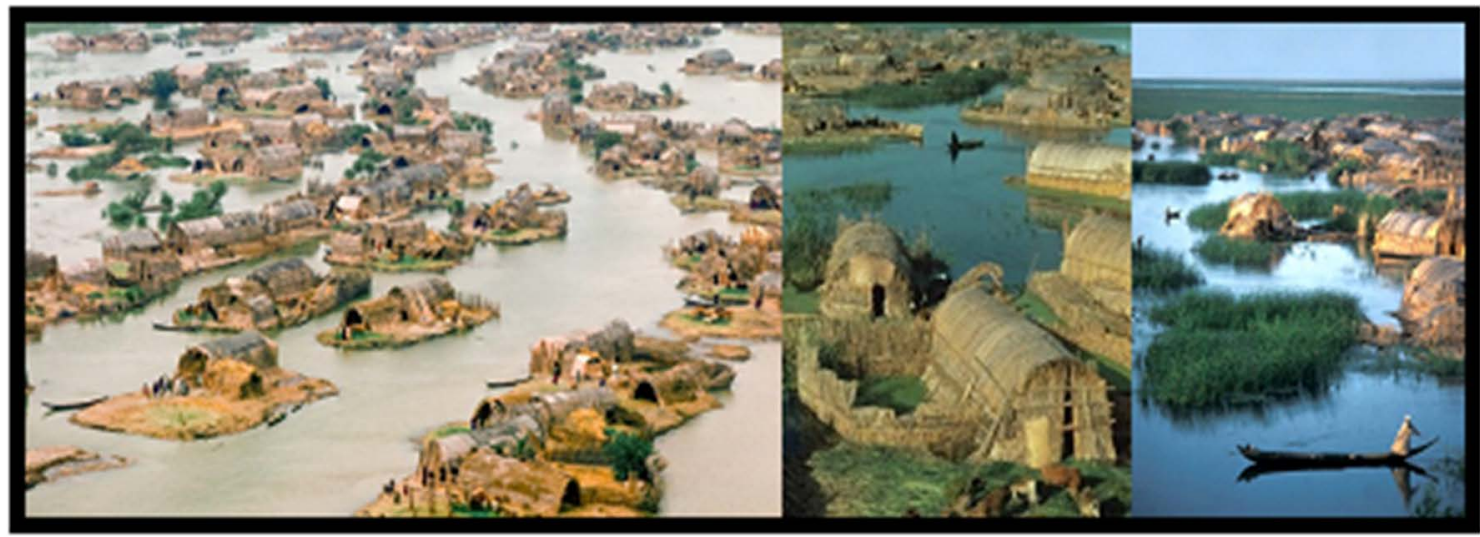

Figure 4. A typical marsh landscape.

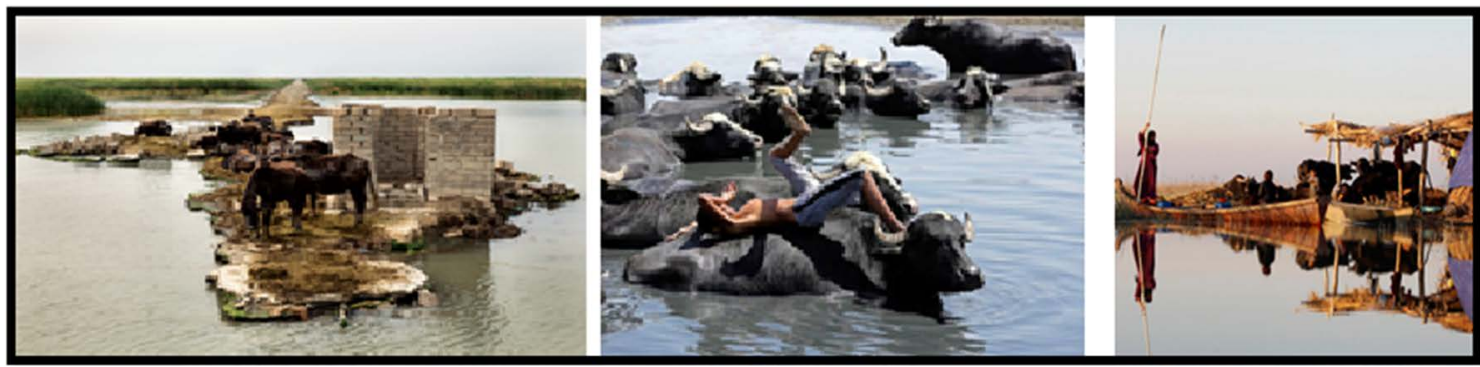

Figure 5. Water buffalos in the marsh area.

fishing, hunting and growing rice are the other complimentary things in the life of the marsh Arabs. The marsh dwellers were isolated until the 1970s.

Reed covers large areas of the marshes while the vegetation in the mud flats is usually Carex and Juncus spp., Scripus brachyceras. In the fresh water lakes, the aquatic vegetation dominates (e.g. hornwort, eel grass and pondweed, as well as bottom vegetation such as stonewart. In the smaller lakes and back swamps, floating vegetation of waterlilies, water soldier and duckweed is common [2] [10].

It has been estimated that $60 \%$ of the fish consumed in Iraq comes from the marshes [11]. Furthermore, oil reserves were discovered in the area [12]. This area is also very important for the migration of birds where several millions of 
birds reside in these marshes when they migrate, and about 80 bird species were used to be in the marshlands [8].

In the 1990s, the Iraqi Government started to dry the marshes for military and security reasons and as a consequence, catastrophic negative effects on the marsh dwellers, animals and plants took place (Figure 6 and Figure 7). After 2003, the new Iraqi government started an attempt to restore the marshes. In this paper, the possibility of restoring the marshes is discussed.

\section{Evolution of the Lower Mesopotamia}

Most of the researchers attribute the climate change and sea level changes were the main factors that caused the development of the marshes and controlling its water quality (Figure 2, Figure 3) [1] [13] [14].

About 18,000 years ago, during the last glacial period, the sea level was below its present level by $120-130 \mathrm{~m}$; this means that the gulf area was dry and the rivers were directly flowing to the gulf of Oman [15]. The river was cutting about -26 to $-30 \mathrm{~m}$ into the Mesopotiaman plain. Most probably there were no marshes at that period [13] [14] [15]. Later about 9000 years ago on ward, there was a transgression of the sea where water reached Basra area. Then it reached Al Amarah and An Nasiriyah areas about 7000 to 6000 years ago (Figure 8 and Figure 9). This period known as the great flood period. It was reported that the
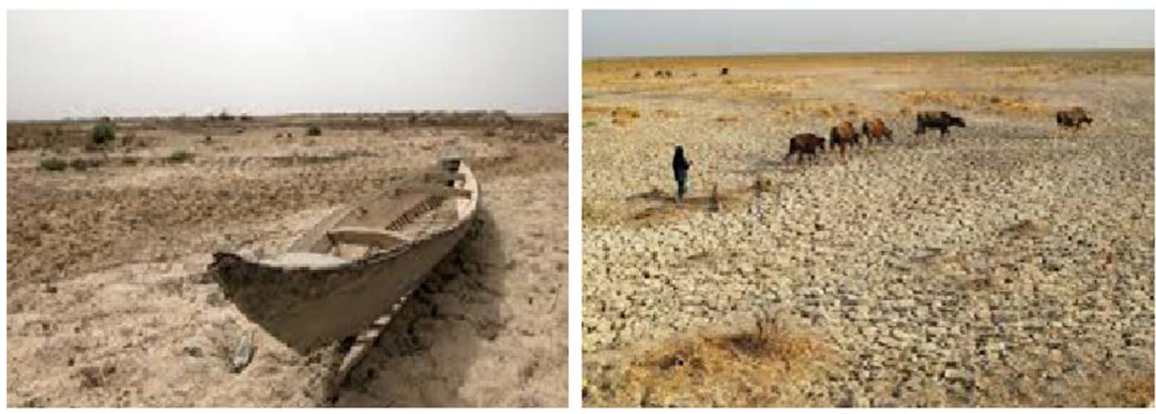

Figure 6. Marsh areas after drying.

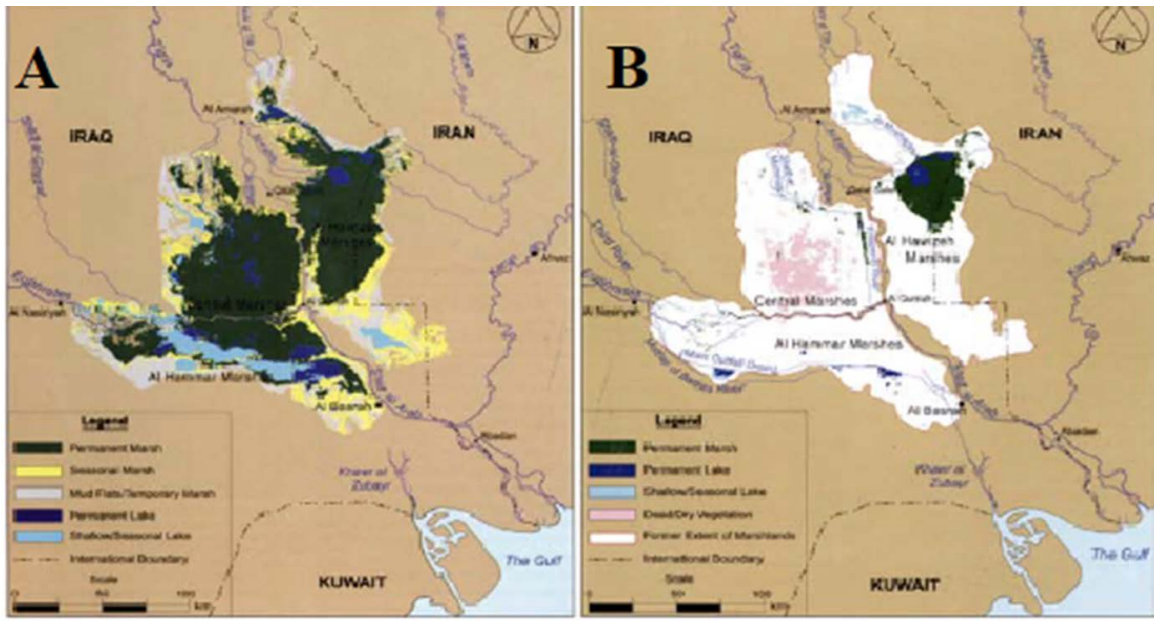

Figure 7. (A) The marshland in 1973. (B) The marshland in 2000 [4]. 


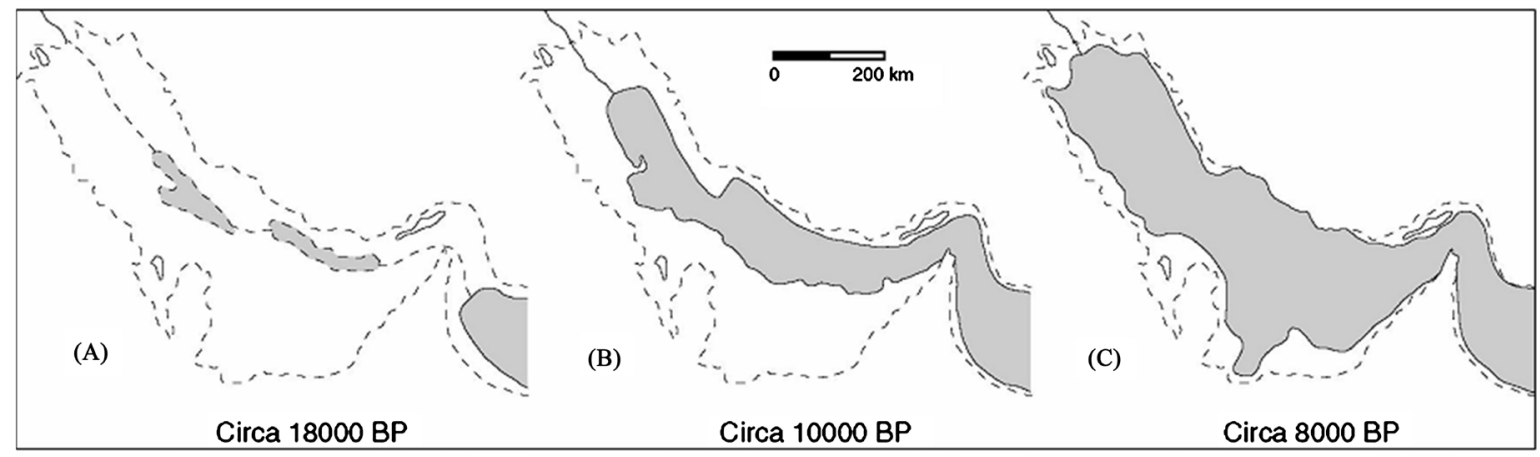

Figure 8. Postglacial transgression of the Gulf area [14].

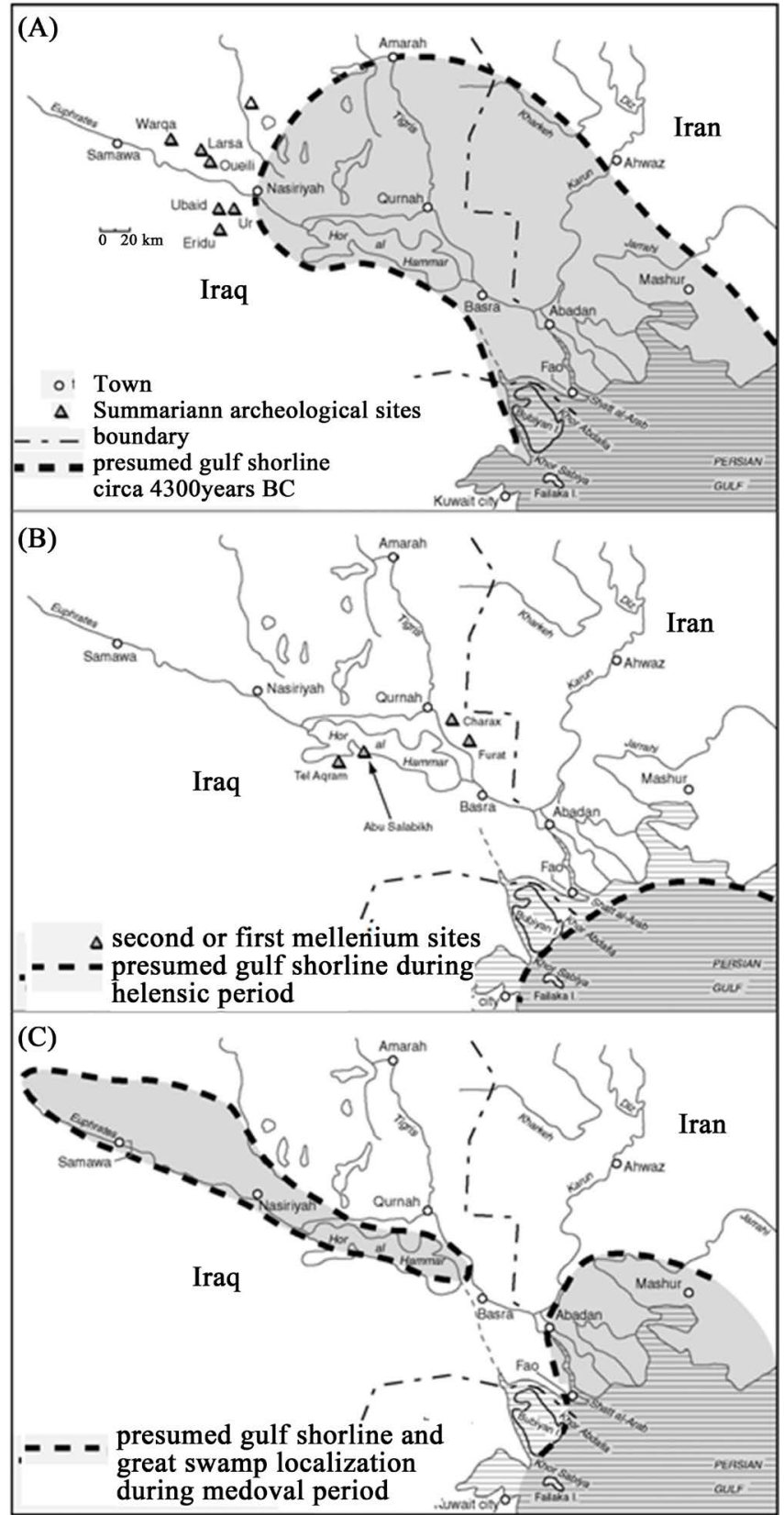

Figure 9. Evolution of the Gulf level and of the Lower Mesopotamian shoreline. 
rise of sea level was relatively fast at this period [16]. This period was followed by semiarid climate that caused regression of the sea level. At this period, the marshes were formed (Figure 8 and Figure 9) [13]. Following that period, the area passed through an arid climate till the current time [13] [17] [18]. Marine fauna was found in Hammar formation (Holocene age) about -2.7 to $-5.8 \mathrm{~m}$ below soil surface, and this indicates that the sea level at that period reached Amrah (Figure 8 and Figure 9) [19] [20]. Above Hammar formation, the sediments are of fluvial nature that were deposited in the shallow northern region of the Gulf leading to the progression of the delta toward the southeast (Figure 9). This changed the nature of the area from the brackish lagoon to fresh water within the formed delta area [21].

Within Hammar marsh and the area east of Qurna-Basra, number of archeological sites were discovered that indicated that during the second and first millennium indicating, the Gulf shoreline was further south. The southern limit of the Mesopotamian delta was very near its present limit during Hellenistic period. During that period, the sea level was about $1 \mathrm{~m}$ lower than its present level [15] [22]. Following this period, no major events took place apart from the Tigris River followed the Gharaf bed into the Euphrates forming a very big marsh $370 \mathrm{~km}$ long and $90 \mathrm{~km}$ wide during the seventh century.

\section{Climate of Marshland}

Generally, the area is characterized by dry hot summer that extends from June to September and mild wet winter that extends from October to May reflecting continental to subtropical climate. Annual precipitation increases from southwest to the northeast (Figure 10). The average annual rainfall in the area ranges from 42 to $185 \mathrm{~mm}$. The long term average annual rainfall within the marshland at the rainy period is between 40 to 60 days, and the probability of intensive rainfall $(1-10 \mathrm{~mm})$ is only $25 \%-27 \%$ [23]. It is noteworthy to mention that October to May, have a relatively low precipitation where the maximum precipitation takes place during December, January to March. Al Amarah, Al Basrah and $\mathrm{Al}$ Nasiriyah stations show an average annual precipitation of 185.42, 152.4 and $109.22 \mathrm{~mm}$ respectively [23] [24].

The average annual temperature is ranging between $22.2^{\circ} \mathrm{C}$ and $27.2^{\circ} \mathrm{C}$ in the marshland area and it reaches more than $500^{\circ} \mathrm{C}$ during summer and sometimes drop below zero during winter (Figure 11). The absolute maximum and minimum are $49^{\circ} \mathrm{C}$ and $-2.2^{\circ} \mathrm{C}-2.8^{\circ} \mathrm{C}$ respectively. The metrological data show that the average maximum and minimum temperatures are $30^{\circ} \mathrm{C}$ and $19^{\circ} \mathrm{C}$ respectively. June, July and August are the warmest months (monthly average $34^{\circ} \mathrm{C}$ $36^{\circ} \mathrm{C}$ ) while January, February and December are the coldest months (monthly average $8.8^{\circ} \mathrm{C}-12.2^{\circ} \mathrm{C}$ ). It should be mentioned, however, that about 10 days a year the temperature is equal or below $0^{\circ} \mathrm{C}$.

As far as the humidity of the area is concerned, it is considered a humid area

(Figure 12) where the humidity reaches its maximum in winter $(67 \%-80 \%)$ and 


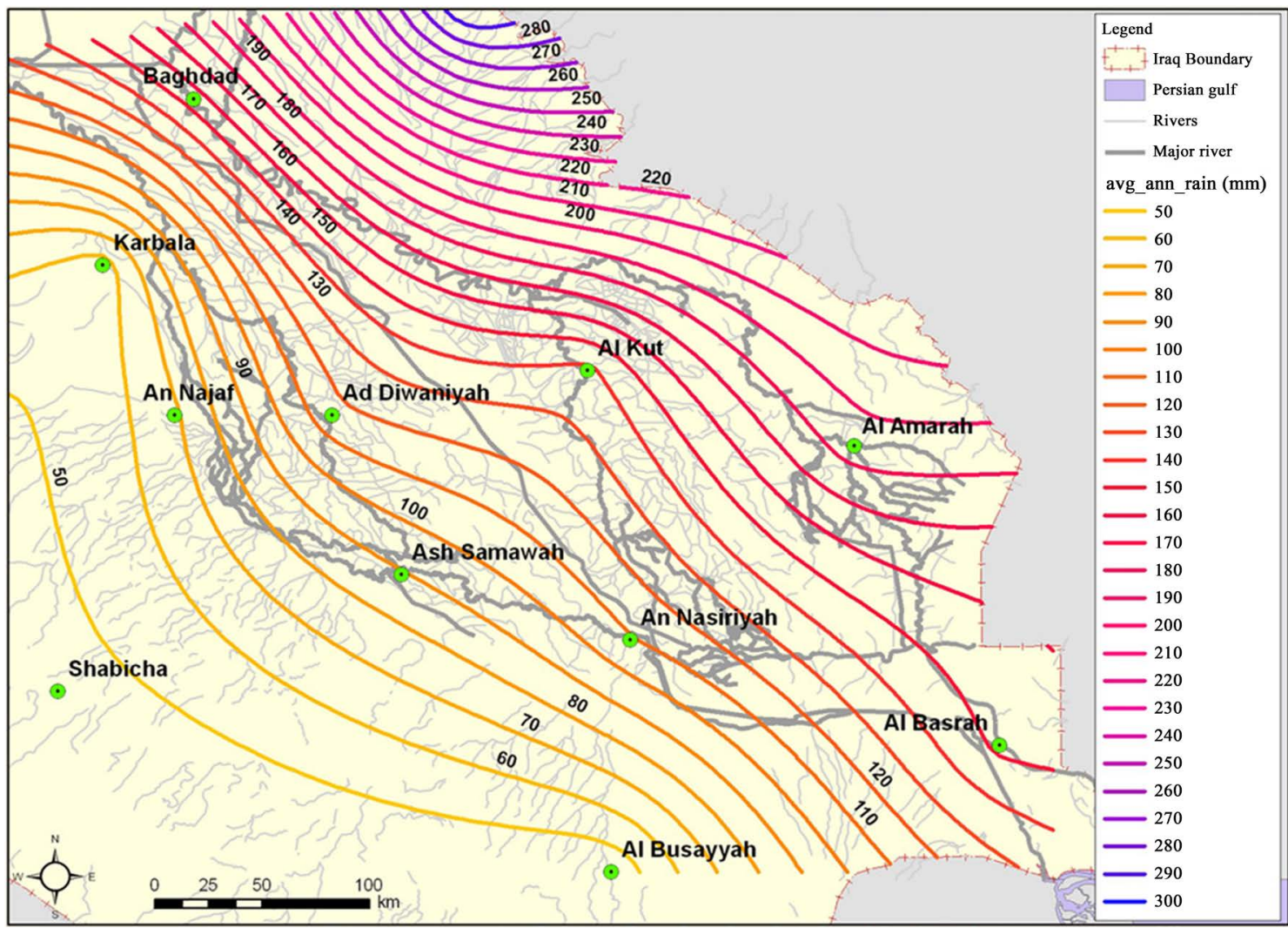

Figure 10. Rainfall distribution area $(\mathrm{mm})$.

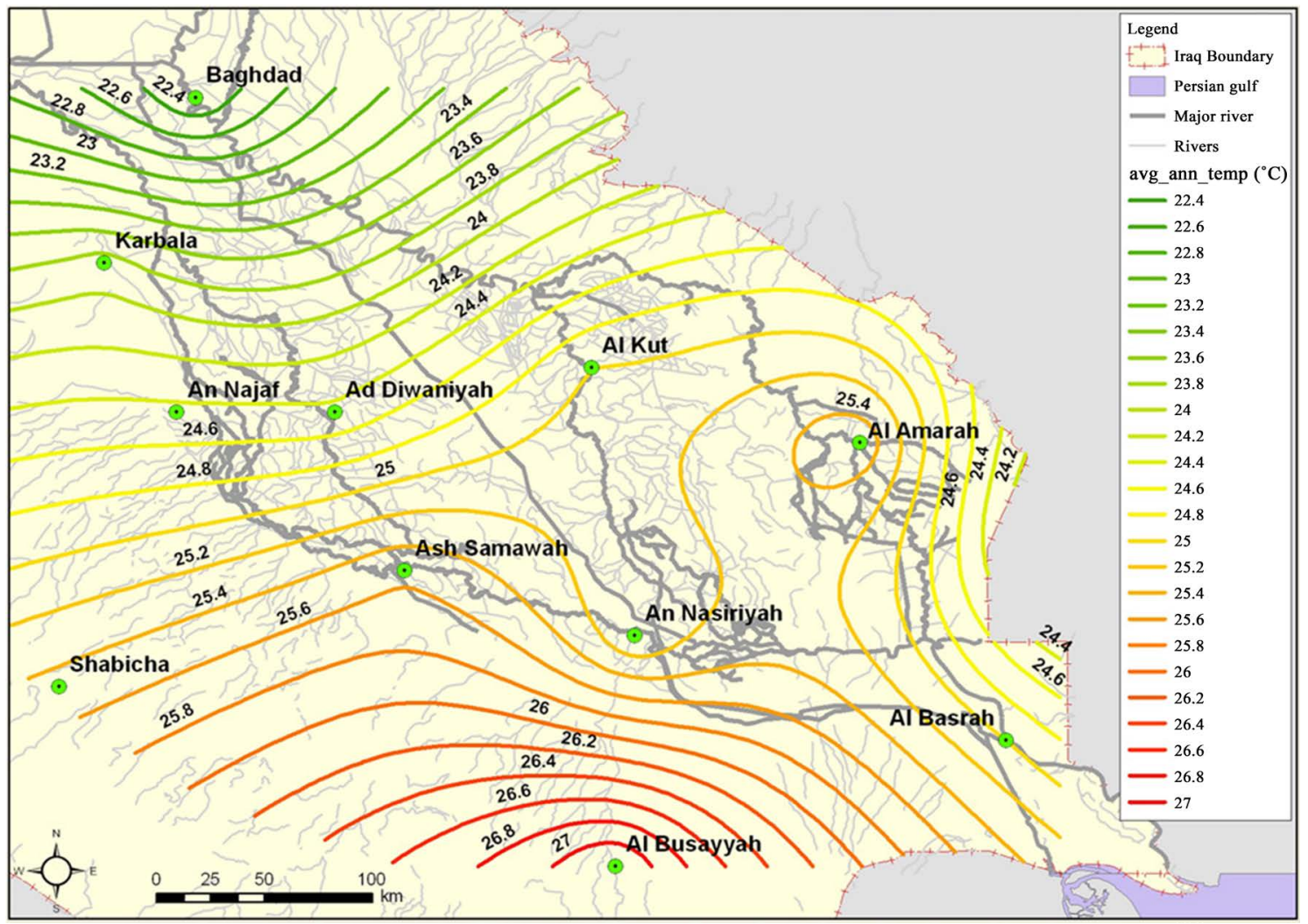

Figure 11. Geographical distribution of mean annual temperature $\left({ }^{\circ} \mathrm{C}\right)$. 


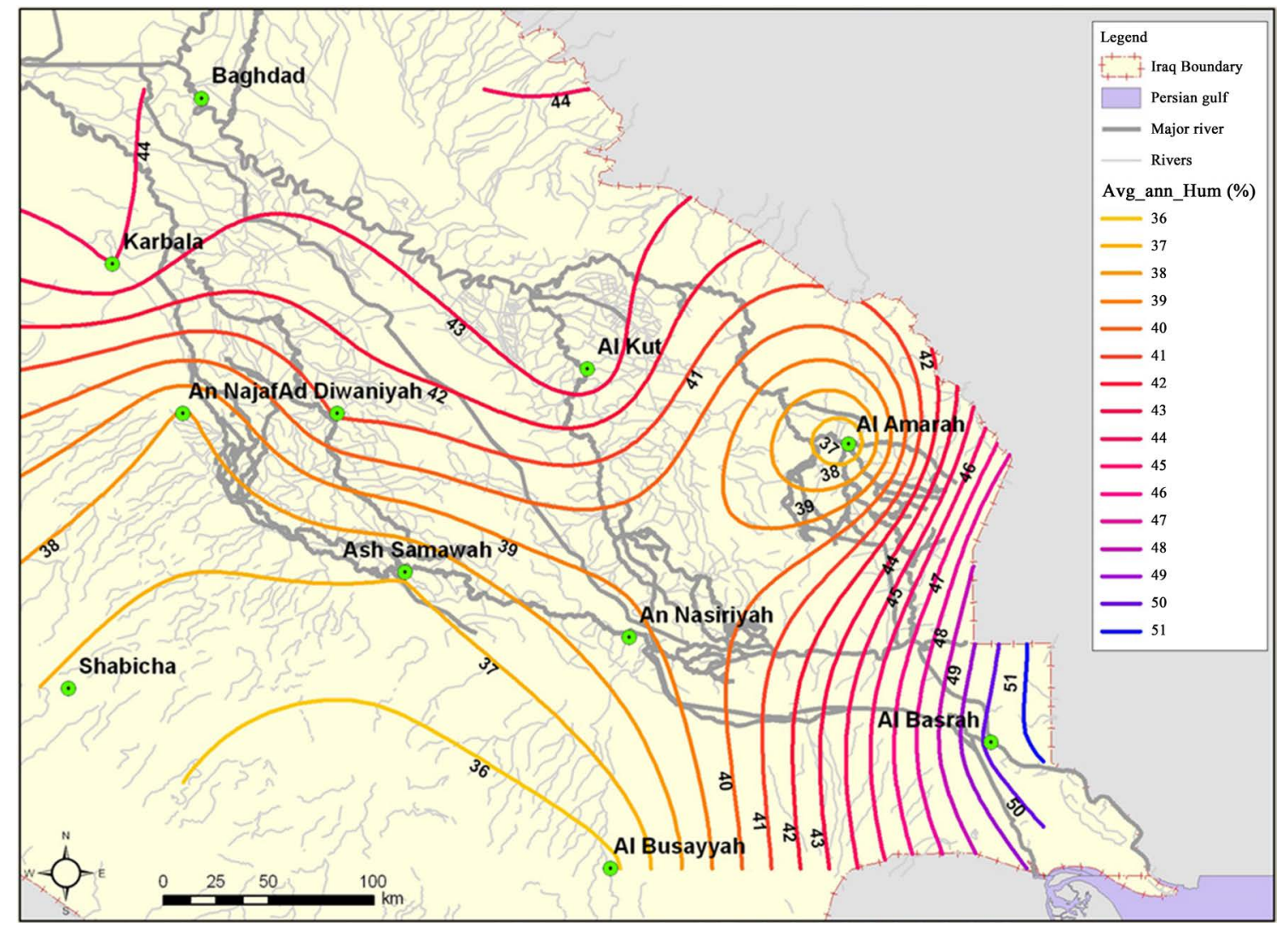

Figure 12. Map of geographical distribution of average annual humidity (\%).

the minimum in summer $(18 \%-27 \%)$ with a mean value of $40 \%-45 \%$. The total annual radiation reaches 525 milliwatt/hour where it reaches its maximum in June and July and its minimum in December and January. Eight to nine hours is the sunshine duration as an average during the day, this is equivalent to $69 \%$ $74 \%$. In summer sunshine duration reaches $80 \%-90 \%$ while in winter it does not exceed $70 \%$. The prevailing wind direction is northwesterly and westerly. During spring, a south-easterly wind present refereed to as "khansin". This wind comes from Saudi Arabia and usually brings sand storms. Mean annual wind velocities are ranging from 3.6 to $5.7 \mathrm{~m} / \mathrm{sec}$ with the highest mean monthly wind velocities taking place in the period June to August. Potential evapotranspiration (ETo) map (Figure 13) shows that the rate is higher in the south relative to the north. The average annual ETo is higher than $2000 \mathrm{~mm}$. ETo reaches its maximum values from May to September and its minimum during January. During summer, $50 \%$ of ETo annual amount occurs while it is $22 \%-23 \%$ during spring and autumn, and it reaches its minimum (6\%) during winter. The average annual day with fog is 27 days, and the maximum number of fog days occurs in December and January. As far as thunderstorms are concerned, its mean annual number of days is 7 usually occurring during the period October to May. The average annual dust days are of the range 36 - 53 days, and they usually occur from April to August with the peak in June and July. The western parts suffer more than other parts from the dust storms. 


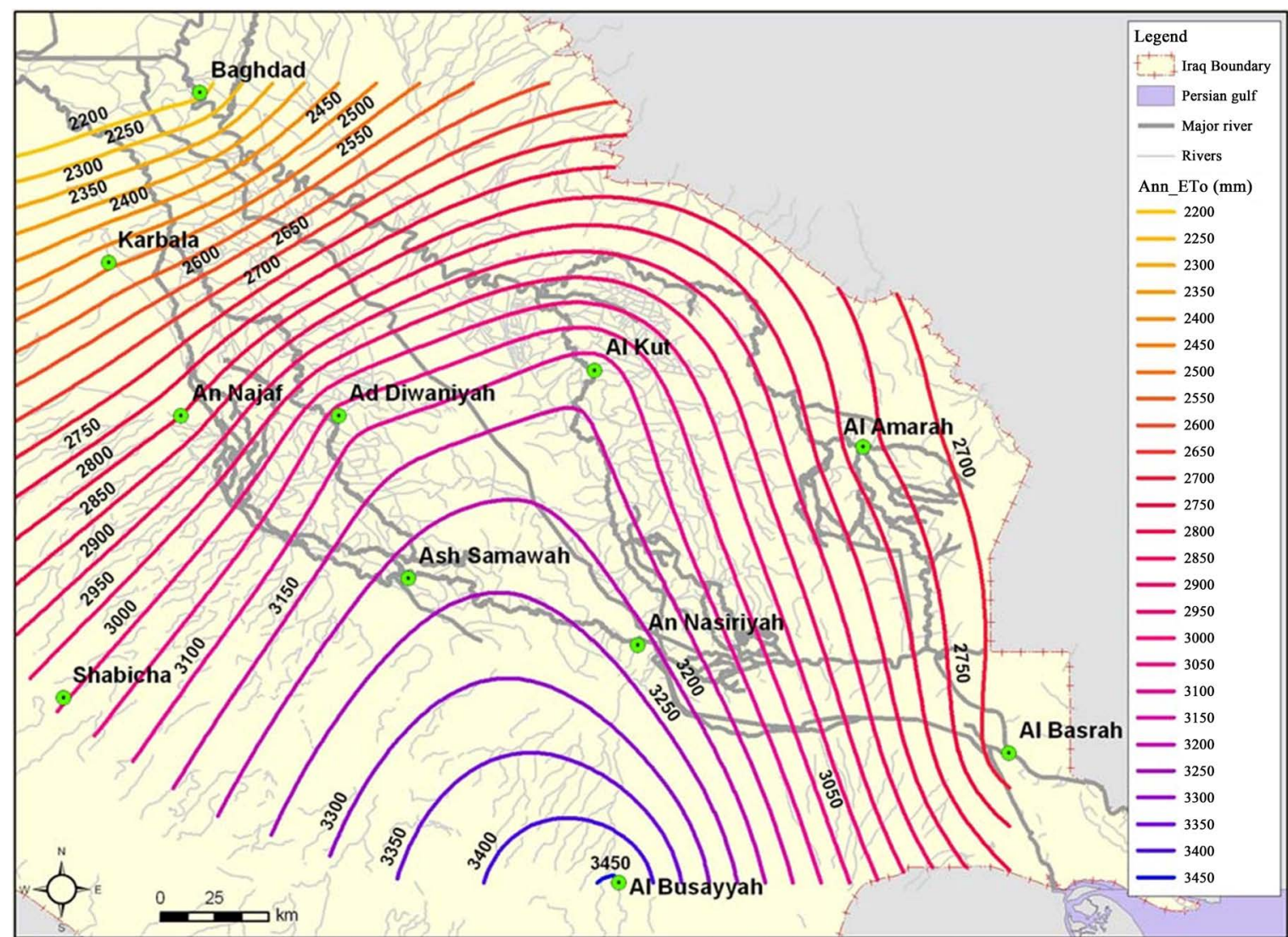

Figure 13. Geographical distribution of mean annual ETo (mm).

\section{The Marshes}

The marshland is located in a very flat area. It rises gently toward the southwestern plateau with an elevation of $940 \mathrm{~m}$ and from the northeast toward Zagros Mountains, which reaches $3000 \mathrm{~m}$. The area is featureless and very plain. The widest portion is about $200 \mathrm{~km}$ while the narrowest portion is about $45 \mathrm{~km}$ near Basrah (Figure 1). There are some areas, which are below sea level. Within the area, the Tigris and Euphrates separate in many sub branches, which disappear in the large marshland that occupies 15,000 - 20,000 square kilometers depending on the availability of water. The main marches in the area are Hammar, $\mathrm{Hu}$ waeizah and Qurnah or Central marches (Figure 1).

\section{Hammar Marsh}

This marsh is located south of the Euphrates River and extends from Nasiriyah in the west to the outskirts of Basrah on Shatt Al-Arab in the east. Toward the south, saline lakes and sand dune belt of the Southern Desert border it. It occupies and area of 2800 square kilometers as a permanent lake before the 1970 's which is about $120 \mathrm{~km}$ long and $25 \mathrm{~km}$ wide. During the flood, it can extend to 4500 square kilometers. The maximum water depth in this marsh is within a range of 1.8 to $3 \mathrm{~m}$. During summer; parts of the wet area dry along its shoreline and banks, and islands emerge. These islands are usually used for agricultural purposes. The main source of water is by flooding and tributaries of 
the Euphrates River. Another source is the overflowing from the Qurnah Marsh, also nourished the Al Hammar Marsh. Groundwater recharge was another source of replenishment.

\section{Qurnah Marshes}

These marshes lie between the Tigris River to the east and the Euphrates River to the south; the area is roughly delimited by a triangle between Nasiriyah, Qalat Saleh and Qurnah. During seventies of last century, the Qurnah Marshes covered an area of about 3000 square kilometers bounded by the Tigris River east and the Euphrates River from the south. These marshes receive water from Tigris's distributaries, namely the Shatt al-Muminah and Majar al-Kabir south of Amarah. The water depth in some areas reaches $3 \mathrm{~m}$. The area consists of reed beds and several permanent lakes including, Umm al Binni Lake. The Al-Zikri and Hawr Umm Al-Binni lakes are two of the notable lakes and are $3 \mathrm{~m}$ deep.

\section{Hawizeh Marshes}

This marsh area is partly located to the east of the Tigris River and some parts in Iran, which is referred to as Hawr Al-Azim. The source of water is by the Karkheh River from Iran, while from Iraq, the Tigris distributaries Al-Musharrah and Al-Kahla supply the marsh. This marsh covers an area of about 3000 square kilometers, and it is $80 \mathrm{~km}$ wide at the north and $30 \mathrm{~km}$ from the south. The southern part is usually seasonal while the central and northern parts are permanent having $6 \mathrm{~m}$ depth of water in some parts. This marsh is characterized by moderately dense vegetation that can be found in the permanent areas.

Hydraulic structure built during the $20^{\text {th }}$ century; construction of major hydraulic works played an essential role in controlling the floods. Al-Hindiya Barrage was inaugurated in 1913 on the Euphrates River while Al-Kut Barrage was constructed in 1938, which directed more water flow towards the Gharraf River to supply irrigation for field agriculture, thereby decreasing the amount of water flowing from the Tigris into the Qurnah (Central) and Huweizah marshes. Details of the hydrological projects built by riparian countries are described later. All these factors reduced the flow of the Tigris and the Euphrates Rivers. Furthermore, many oil fields were discovered within the area that meant drying 1000 square kilometers of the marshes. The main oil fields are:

1) South Rumayllah in the $\mathrm{Al} \mathrm{Hammar} \mathrm{Marsh.} \mathrm{This} \mathrm{is} \mathrm{a} \mathrm{super-giant} \mathrm{oilfield} \mathrm{in}$ production since 1953. The northern portion of the oilfield extends into the marshlands. Approximately $300 \mathrm{~km}^{2}$ of marshlands have been drained to accommodate its production footprint.

2) North Rumayllah in the Hammar Marsh. North Rumayllah was discovered shortly after the main Rumayllah field in 1954, but did not go online until 1972. Approximately $200 \mathrm{~km}^{2}$ of marshlands were drained to accommodate its production footprint.

3) Zubayr field within the southeastern most Hammar Marsh. This oilfield has been producing since 1949; approximately $100 \mathrm{~km}^{2}$ of marshland were drained to allow for production facilities. 
4) West Qurnah in the Hammar and Qurnah Marshes. This is essentially the northern extension of the Rumayllah oilfields and represents a separate super-giant oilfield. The field was initially developed in the late 1980s. Only the portion within Hammar Marsh is under production, for which an area of about $150 \mathrm{~km}^{2}$ of marshlands was drained.

5) Majnoon Field within the Huweizah Marsh. This is a super-giant oilfield discovered in 1977. Approximately $300 \mathrm{~km}^{2}$ of marshlands were drained to accommodate the footprint of its production facilities.

After the 1990s, the Iraqi Government started to drain the marshes for military and security reasons and 63\% of the marshes disappeared in 1992 compared to 1985 (Table 1) [25]. To enable the army to move inside the marshes, the central government started to execute five major drainage projects to prevent water from the Tigris and Euphrates Rivers from reaching the marches that were constructed to drain the marshes are discussed in details by [26] [27] [28] [29]. Later, the army launched a major attack against marsh dwellers using artillery, mortar and ground attacks [30] [31] [32]. Two third of the marshes were not receiving water inputs in 1993 and in 2000 less than 10\% remained [33]. The population of marsh's dwellers before 1990 was about 500,000 and due to the military activities' 120,000 marsh dwellers left to Iran [33] [34]. Later, in 1997, 192,000 marsh dwellers were still living southern Iraq, and 200,000 remained in all Iraq [35]. Some local dwellers turned to farming to survive. This caused a number of negative environmental implications. One of the implications is poor water quality [4] [36] [37]. It should be mentioned, however, that the area was

Table 1. Land cover classification and change in the Marshes area 1977-2000 [25].

\begin{tabular}{|c|c|c|c|}
\hline \multicolumn{4}{|c|}{ Hammar Marsh } \\
\hline Land cover Category & $1977\left(\mathrm{~km}^{2}\right)$ & $1985\left(\mathrm{~km}^{2}\right)$ & $1985\left(\mathrm{~km}^{2}\right)$ \\
\hline Permanent Marsh & 1632 & 2347 & 60 \\
\hline Seasonal Marsh/Agriculture & 286 & 339 & 210 \\
\hline Open Water & 1933 & 694 & 112 \\
\hline Total Permanent Wetland & 3565 & 3041 & 172 \\
\hline \multicolumn{4}{|c|}{ Qurnah Marsh } \\
\hline Permanent Marsh & 2765 & 3244 & 82 \\
\hline Seasonal Marsh/Agriculture & 380 & 190 & 689 \\
\hline Open Water & 646 & 203 & 66 \\
\hline Total Permanent Wetland & 3411 & 3447 & 148 \\
\hline \multicolumn{4}{|c|}{ Hawizeh Marsh } \\
\hline Permanent Marsh & 2408 & 2496 & 973 \\
\hline Seasonal Marsh/Agriculture & 286 & 224 & 507 \\
\hline Open Water & 785 & 766 & 173 \\
\hline Total Permanent Wetland & 3193 & 3262 & 1146 \\
\hline
\end{tabular}


highly contaminated by army munitions and poison gas [28] [31] [38].

Later, after 2003, people living near the marshes started to break down the diversions' structures to let water entering the marsh lands [33]. The Iraqi Government and the International community started to restore the marshes. Vegetation and wetland increased by $58 \%$ and the marshland was covering an area of 44,950 square kilometers in 2008 . Then, the area was reduced to 3420 square kilometers in April 2009 and to 2313 square kilometers in July 2009 [33] [39]. The area increase and decrease variations are due to water availability and shortages. For this reason, this phenomenon continued with time (see Figure 14).

\section{How Much Water Is Required to Restore the Marshes?}

The volume of water required to restore $75 \%$ of the marshes is about $13 \mathrm{BCM}$ (Table 2) [40]-[57]. To find out this; we have to look at the whole water availability in Iraq. Water resources in Iraq mainly depend on the volume of water of the Tigris and Euphrates and their tributaries that enter in Iraq from other riparian countries (Figure 15) [40] [41] [42] [43] [44]. The two rivers rise in Turkey
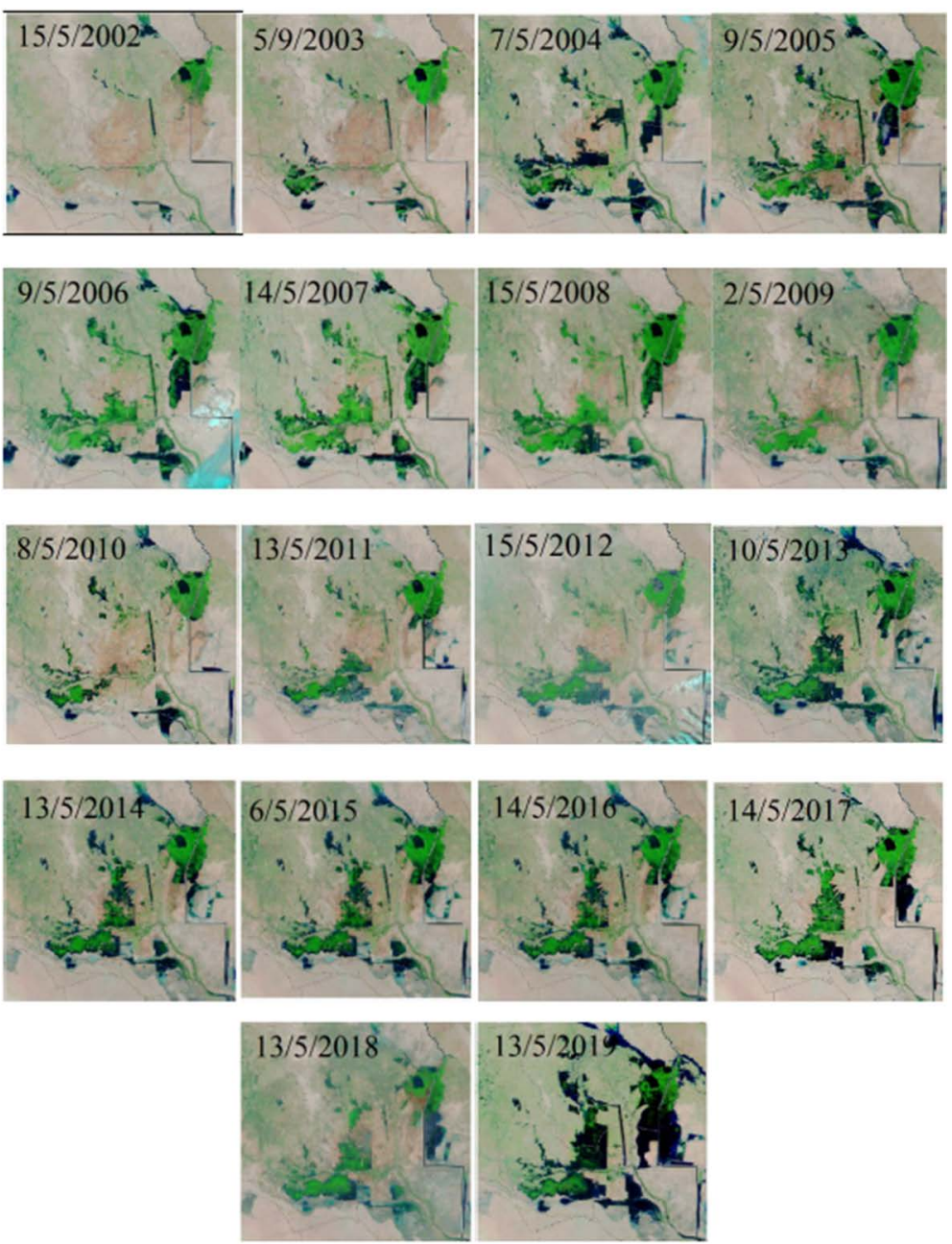

Figure 14. Changes of the area covered by the marshes for the period 2002 to 2019 according to the availability of water. 
Table 2. The volume of water required to restore the Iraqi marshes.

\begin{tabular}{ccccc}
\hline Marsh & $\begin{array}{c}\text { Total available area } \\
\mathbf{k m}^{\mathbf{2}}\end{array}$ & $\begin{array}{c}\text { \% restored area } \\
\mathbf{2 0 0 8}\end{array}$ & \% goal area & $\begin{array}{c}\text { Water required } \\
\text { BCM }\end{array}$ \\
\hline Huweizah & 1800 & 44 & 75 & 5495 \\
Hammar & 1800 & 23 & 75 & 3263 \\
Qurnah & 2425 & 25 & 75 & 4128 \\
Total & & & & $\mathbf{1 2 , 8 8 6}$ \\
\hline
\end{tabular}

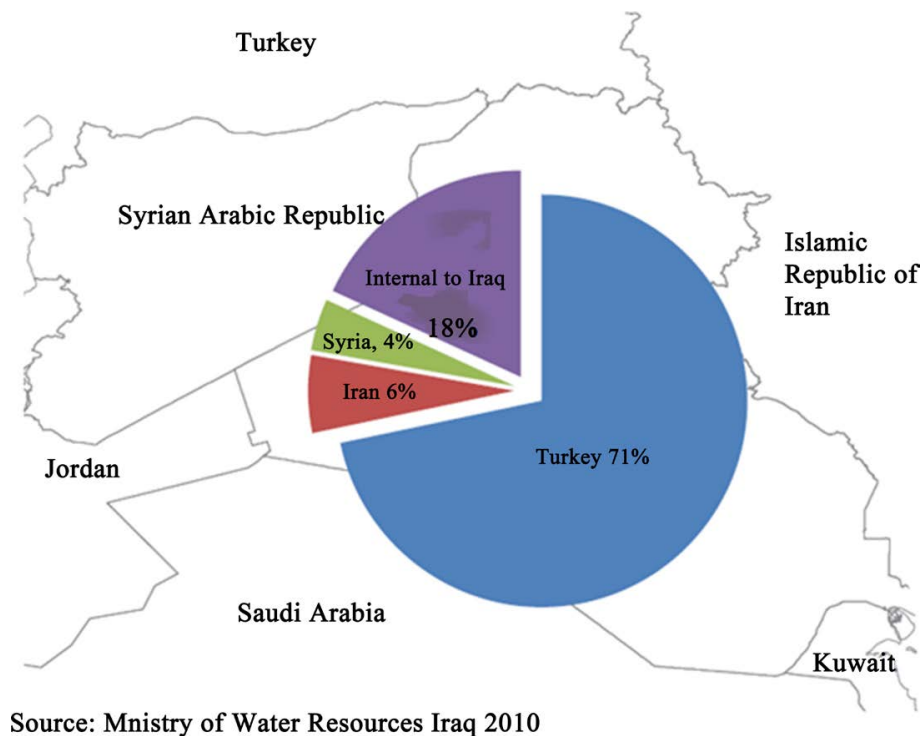

Figure 15. Water supply by country within the Tigris and Euphrates basins to Iraq.

while some of the tributaries of the Tigris rise in Iran. Any activity within Turkey and Iran affects the quantity and quality of the water entering Iraq.

Long-term average quantity of water entering Iraq from main Tigris and its tributaries are about 21.2 and $24.78 \mathrm{BCM}$ while the Euphrates long average annual flow that is received by Iraq is about 30 BCM [40]-[47]. Since the 1970s, the flow of the two rivers and their tributaries started to decrease. The flow of the Tigris River and its tributaries at Baghdad was 1207 cumecs for the period 1931-1960 and it dropped to 927 and 522 cumecs for the periods 1961-2000 and after the year 2000 respectively. The average annual flow of the Euphrates started to decrease from $30 \mathrm{BCM}$ to about 4.4 BCM. This decrease of the flow of the rivers is due to the projects executed in Turkey, Iran and Syria and climate change [48]-[63].

Turkey, Iran and Syria started to build dams in the upper parts of the catchment (Tables 3-5). Turkey started to execute what is known as the GAP project. This project involves 22 dams and 19 power generation plants (Table 3) [64] [65]. Iran blocked the Karoon River which supplies about 50\% of the flow of Shat Al-Arab River. In addition, other dams were constructed and all the valleys entering Iraq from Iran were diverted (Table 4) [42] [43]. Syria constructed 4 dams (Table 5) only, and this is due to the security situation in that country. All 
Table 3. Dams constructed by turkey on the rivers Euphrates and Tigris.

\begin{tabular}{|c|c|c|c|c|}
\hline Dam & River & Height (m) & Purpose & Completion Date \\
\hline Çetin Dam (Alkumru) & Tigris/Botan & 145 & $\mathrm{P}$ & 2016 \\
\hline Aslanda $\bar{g}$ & Tigris/Greater Zab/Bembo & 60 & I/M/P (future) & 2012 \\
\hline Beyyurdu & Tigris/Greater Zab/Bembo & 48 & I/M/P (future) & Under Construction \\
\hline Atatürk (Karababa) & Euphrates & 169 & $\mathrm{P}$ & 1992 \\
\hline Balli & Tigris/Khabour/Hezil/Ortasu & 49 & $\mathrm{I} / \mathrm{M} / \mathrm{P}$ & Under Construction \\
\hline Batman & Tigris/Batman & 74 & $\mathrm{I} / \mathrm{P}$ & 1999 \\
\hline Beyhan I & Euphrates/Murat & 97 & $\mathrm{P}$ & 2015 \\
\hline Beyhan II & Euphrates/Murat & 62 & $\mathrm{P}$ & Planned \\
\hline Birecik & Euphrates & 62.5 & $\mathrm{I} / \mathrm{P}$ & 2001 \\
\hline Burḉ Bendi & Euphrates/Gö̈ksu & 47 & $\mathrm{P}$ & 2010 \\
\hline Cizre & Tigris/Botan & 46 & $\mathrm{I} / \mathrm{P}$ & Planned \\
\hline Çoukurca & Tigris/Greater Zab/Güzedlere & 45.5 & $\mathrm{~W} / \mathrm{M}$ & Under Construction \\
\hline Dumluka & Euphrates/Bugur & 30 & I & 1991 \\
\hline Erkenek & Euphrates/Adiyaman & - & $\mathrm{p}$ & Operational \\
\hline Gö̈ksu & Euphrates/Gö̈ksu & 52 & I & 1991 \\
\hline Hecihider & Euphrates/Sehir & 42 & I & 1989 \\
\hline Hancaḡiz & Euphrates/- & - & I & 1988 \\
\hline Ilisu & Tigris & 135 & $\mathrm{I} / \mathrm{P} / \mathrm{F}$ & 2017 \\
\hline Upperkalekö̈y & Euphrates/Murat & 137.5 & $\mathrm{P}$ & 2017 \\
\hline Lower kalekö̈y & Euphrates/Murat & 115 & $\mathrm{P}$ & Planned \\
\hline Karakaya & Euphrates & 158 & $\mathrm{P}$ & 1987 \\
\hline Karkamiṣ & Euphrates & 21.1 & $\mathrm{P}$ & 2000 \\
\hline Kavsaktepe & Tigris/Khabour/Hezil/Ortasu & 66 & $\mathrm{~W} / \mathrm{M}$ & Under Construction \\
\hline Kayacik & Euphrates/Sajur & 45 & $\mathrm{I} / \mathrm{P}$ & 2005 \\
\hline Keban & Euphrates & 207 & $\mathrm{P}$ & 1974 \\
\hline Kirazlik & Euphrates/Botan & 60 & $\mathrm{I} / \mathrm{P}$ & 2011 \\
\hline Kralkizi & Tigris/Maden & 113 & $\mathrm{I} / \mathrm{P}$ & 1997 \\
\hline Musatatepe & Tigris/Khabour/Hezil/Ortasu & 34.5 & $\mathrm{~W} / \mathrm{M}$ & Under Construction \\
\hline Silope & Tigris/Khabour/Hezil & 79.5 & $\mathrm{~W} / \mathrm{M} / \mathrm{P}$ & 2012 \\
\hline Silvan & Tigris/Batman & 174.5 & $\mathrm{I} / \mathrm{P}$ & 2017 \\
\hline Sirrntiș & Tigris/Birimşe & 92 & I & 2013 \\
\hline Șirnak & Tigris/Khabour/Hezil/Ortasu & 56.8 & $\mathrm{~W} / \mathrm{M}$ & 2012 \\
\hline Uludere & Tigris/Khabour/Hezil/Ortasu & 55.5 & $\mathrm{~W} / \mathrm{M}$ & Under Construction \\
\hline
\end{tabular}

F: Flood Control I: Irrigation M: Military P: Power W: Water supply. 
Table 4. Dams constructed by Iran on the tributaries of the river Tigris.

\begin{tabular}{ccccc}
\hline \multirow{2}{*}{ Dam } & River & Height $(\mathrm{m})$ & Purpose & $\begin{array}{c}\text { Completion } \\
\text { Date }\end{array}$ \\
\hline Dez & Shatt Al-Arab/Karun & 203 & I/P & 1963 \\
Shahid Abbaspour (Karun 1) & Shatt Al-Arab/Karun & 200 & $\mathrm{P}$ & 1976 \\
Masjed Sulaayman (Karun 2) & Shatt Al-Arab/Karun & 164 & $\mathrm{P}$ & 1976 \\
Karun 3 & Shatt Al-Arab/Karun & 205 & I/P/F & 2002 \\
Karun 4 & Shatt Al-Arab/Karun & 230 & I/P/F & 2010 \\
Garan & Tigris/Diyala/Sirwan & 62 & I & 2005 \\
Darayan & Tigris/Diyala/Sirwan & 169 & I/P & 2010 \\
Upper Gotvand & Shatt Al-Arab/Karun & 180 & P & 2012 \\
Lowe Gotvand & Shatt Al-Arab/Karun & 22 & P & 1977 \\
Karkha & Shatt Al-Arab/Karkha & 127 & I/P & 2001 \\
Seimare & Shatt Al-Arab/Karkha & 180 & P & 2013 \\
Khersan 3 & Shatt Al-Arab/Karun/Karkha & 195 & P/F & 2015 \\
\hline
\end{tabular}

F: Flood Control I: Irrigation M: Military P: Power W: Water supply.

Table 5. Dams constructed by Syria on the River Euphrates.

\begin{tabular}{ccccc}
\hline Dam & River & Height $(\mathrm{m})$ & Purpose & Completion Date \\
\hline Baath & Euphrates & 14 & P, I, F & 1988 \\
Tabaqa & Euphrates & 60 & P, I & 1975 \\
Tishrine & Euphrates & 40 & P & 1999 \\
Upper Khabour & Khabour & & I & 1992 \\
\hline
\end{tabular}

F: Flood Control I: Irrigation M: Military P: Power W: Water supply.

these projects caused a decrease in the flow of the rivers and decrease in the water quality of the river too.

Furthermore, climate change also affected the flow of the two rivers. All research carried out concerning the Middle East indicates that this area is suffering more than other areas in the world due to climate change, and this caused decrease of precipitation and increase of the temperature [42]-[63]. Prediction models indicate that there will be $15 \%-25 \%$ reduction in precipitation, and that will cause a reduction of surface water flow about $29 \%$ to $73 \%$. This situation will cause grave depletion of groundwater resources. Water scarcity will affect agriculture, municipal water supply, sanitation industry and life quality. It is expected that Iraq will suffer from water shortages where it will reach $-20.6 \mathrm{BCM}$ in 2040 [66].

In view of the above, prudent strategic water management plan is required. The main outlines are such a plan should include:

- Projects in riparian countries.

- Climate change effect. 
- -Using modern irrigation techniques and highly consuming water plants and vegetables is to be avoided.

- Using non-conventional water resources.

- Public awareness program is to be put into practice.

- Maintenances of all existing projects.

- Executing new suggested dams.

- Human resources development plan.

- Discussions with riparian countries about Iraq's water share from the rivers. The details of such plan are given by [40] [42] [43] [44] [45] [47].

In addition, in case the situation remains as it is, all future predictions suggest that all riparian countries will be under water shortage stress. Bilateral talks and/or agreements are not sufficient to begin discussions for a regional solution. Therefore, such negotiations and discussions require a third party to intervene to bring all riparian countries together. To reach a final solution and sign an agreement between riparian countries this requires an external mediator that can highlight and frame the issues in such a way that each country believes that it is gaining by joining the discussion and will lose something by avoiding the discussions. The third party (mediator) should be influential on the international political level, has the capability of financial support and has high technical skills that can be used. In such a case, all parties will be seriously involved in the discussions. Furthermore, it is believed that such negotiations between Iraq and others should include commercial, agricultural, industrial, military and security, trade and water. This is because Turkey is the dominant regional power and will not take the discussion seriously unless there are incentives.

In this context, it is believed that if this plan is put into practice, the water can be made available to restore the marshes.

\section{Conclusion}

Iraqi marshes are located within the southern part of Iraq where the Tigris and Euphrates Rivers join in a very gentle slope area (4 to $8 \mathrm{~cm} / \mathrm{km}$ ). The marshes used to cover an area 15,000 - 20,000 square kilometers, and about 500,000 people used to live within that area. After the first Gulf war, the government of Iraq started to dry the marshes since 1990 for military and security reasons. Oil companies started to work in that area and some of the locals used some areas for agricultural activities, and this led to be occupied about $25 \%$ of the marsh area. After 2003, the government changed and they started to restore the remainder $75 \%$ of marshes. To achieve this goad they require about 13 billion $\mathrm{cu}-$ bic kilometers of water (BCM). The problem was the scarcity of water due to the building of dams in riparian countries and climate change. It is believed that if the government has to change its strategy of water resources management because the existing strategy will lead to more water scarcity problems. A new strategy must reach agreements with riparian countries to secure the amount of water that Iraq should get from the Tigris and Euphrates rivers and their tribu- 
taries. In addition, this strategy should seriously consider scientific outlines to consider the effect of climate change and modernizing irrigation techniques and maintenance of existing water and agricultural projects. The use of non-conventional water resources use, and public awareness programs are to be put in practice.

\section{Acknowledgements}

The author would like to thank Professor Husain Musa Hussain of Remote Sensing Center, University of Kufa, Iraq for providing the satellite photos.

\section{Conflicts of Interest}

The author declares no conflicts of interest regarding the publication of this paper.

\section{References}

[1] UNEP (2006) Iraqi Marshlands Observation System. UNEP Technical Report, 71. https://postconflict.unep.ch/publications/UNEP_IMOS.pdf

[2] Scott, D. (1995) A Directory of Wetlands in the Middle East. IUCN, Gland and IWRB, Slimbridge.

[3] Maltby, E. (1994) An Environmental and Ecological Study of the Marshlands of Mesopotamia. Draft Consultative Bulletin. Wetland Ecosystems Research Group, University of Exeter. The AMAR Appeal Trust, London.

[4] UN (2011) Managing Change in the Marshlands: Iraq's Critical Challenge. United Nations Integrated Water Task Force for Iraq. http://iq.one.un.org/Water-in-Iraq

[5] Iraqi Government (2014) The Ahwar of Southern Iraq: Refuge of Biodiversity and the Relict Landscape of the Mesopotamian Cities, Nomination Dossier for Inscription of the Property on the World Heritage List. 268 p. https://www.google.com/url?sa=t\&rct=j\&q=\&esrc=s\&source=web\&cd=\&cad=rja\& uact=8\&ved=2ahUKEwjD1 ujmyKvqAhWmy6YKHVipBuUQFjABegQIAxAB\&url= https\%3A\%2F\%2Fwhc.unesco.org\%2Fdocument\%2F169032\&usg=AOvVaw1NWq VCKE5VR1SRzBPwq5Lf

[6] Ansari, N.A. (2005) Applied Surface Hydrology. Al al-Bayt University Publication, Jordan.

[7] Al-Ansari, N.A. and Salmah, E. (1995) Water and Civilization. Al-Zahra, 2, 6-10.

[8] UNEP (2001) The Mesopotamian Marshlands: Demise of an Ecosystem. Early Warning and Assessment Technical Report, 47.

https://eoimages.gsfc.nasa.gov/images/imagerecords/1000/1716/meso2.pdf

[9] Roux, G. (1993) Ancient Iraq. Penguin, Hamrondsworth.

[10] Rechinger, K. (1964) Flora of Lowland Iraq. Hafner Publishing Ltd., New York.

[11] Canada Iraq Marshlands Initiative (2010) Iraq Marshlands Initiative. http://oia.uvic.ca/?q=node/944 https://www.acronymattic.com/Canada-Iraq-Marshlands-Initiative-(CIMI).html

[12] Naff, T. and Hanna, G. (2003) The Marshes of Southern Iraq: A Hydro-Engineering and Political Profile. In: Nicholson, E. and Clark, P., Eds., The Iraqi Marshlands. $A$ Human Environmental Study, 2nd Edition, Politico's Publishing, London, 169-200.

[13] Aqrawi, A.A.M. (1995) Correction of Holocene Sedimentation Rates for Mechanical 
Compaction: The Tigris-Euphrates Delta, Lower Mesopotamia. Marine and Petroleum Geology, 12, 409-416. https://doi.org/10.1016/0264-8172(95)96903-4

[14] Al-Ansari, N.A., Knutsson, S. and Ali, A. (2012) Restoring the Garden of Eden, Iraq. Journal of Earth Sciences and Geotechnical Engineering, 2, 53-88.

[15] Sanlaville, P. (2001) The Deltaic Complex of the Lower Mesopotamian Plain and Its Evolution through Millennia. In: A Human and Environmental Study, AMAR International Charitable Foundation, London, 94-109.

[16] Lambeck, K. (1996) The Persian Gulf since the Last Glacial Maximum: A Palaeogeographic Reconstruction. Earth Planetary Science Letters, 142, 43-57. https://doi.org/10.1016/0012-821X(96)00069-6

[17] Gunatilaka, A. (1986) Kuwait and the Northern Arabian Gulf: A Study on Quaternary Sedimentation. Episodes, 9, 223-231. https://doi.org/10.18814/epiiugs/1986/v9i4/004

[18] Al-Zamel, A.Z. (1985) Occurrence and Age of Submarine Peat in the Euphrates-Tigris Delta. S.E.P.M. Midyear Meeting, Golden, Abstracts 4.

[19] Macfadyen, W.A. and Vita-Finzi, C. (1978) Mesopotamia: The Tigris-Euphrates Delta and Its Holocene Hammar Fauna. Geological Magazine, 115, 287-300. https://doi.org/10.1017/S0016756800037183

[20] Hudson, R.G.S., Eames, F.E. and Wilkins, G.L. (1957) The Fauna of Some Recent Marine Deposits near Basra, Iraq. Geological Magazine, 94, 395-398.

https://doi.org/10.1017/S0016756800069429

[21] Admiralty Intelligence Division (1944) The Handbook of Iraq and the Persian Gulf. HMSO, London.

https://s3-eu-west-1.amazonaws.com/live.archive.pdf/81055_vdc_100000000239.0x 000178_en.pdf

[22] Dalongeville, R. (1990) Présentation physique générale de l'île de Failaka. In: Calvet, Y. and Gachet, J., Eds., Failaka. Fouilles françaises 1986-1988, Travaux de laMaison de l'Orient, Lyon, 23-40.

[23] Iraqi Ministries (2006) New Eden Master Plan for the Integrated Water Resources Management.

[24] Alex, M. (1985) Klimadaten ausgewahlter stationen des Vorderen Orients. Tubinger Atlas.

[25] Brasington, J. (2001) Monitoring Marshland Degradation Using Multispectral Remote Sensed Imagery. In: Clark, P. and Magee, S., Eds., The Iraqi Marsh Lands: $A$ Human and Environmental Study, The AMAR International Charitable Foundation, UK, 110-132.

https://reliefweb.int/report/iraq/iraqi-marshlands-human-and-environmental-study

[26] CRIM (2007) Study the Rehabilitation of Al Huweizah Marsh Ecological System. Ministry of Water Resources, Center of Restoration of Iraqi Marshes, Baghdad, Vol. 1 to 7 .

[27] CRIM (2008) Study of Restoration of Al Hammar Marsh. Ministry of Water Resources, Center of Restoration of Iraqi Marshes, Baghdad.

[28] CRIM (2009) Study of Improving the Environmental Present Conditions of Southern Marshes (Al Hammar, Al Huwaeizah Central and Aby-Zirig). Ministry of Water Resources, Center of Restoration of Iraqi Marshes, Baghdad.

[29] Tkachenko, A. (2003) The Economy of the Iraqi Marshes in the 1990s.

[30] CRIM (2009) Water, Marshlands and Nearby Countries. Presentation, Ministry of Water. 
[31] Benvenisti, E. (2003) Water Conflicts during the Occupation of Iraq. The American Journal of International Law, 97, 860-872. https://doi.org/10.2307/3133685

[32] Sluglett, P. (2003) The Marsh Dwellers in the History of Modern Iraq. In: Nicholson, E. and Clark, P., Eds., The Iraqi Marshlands: A Human and Environmental Study, 2nd Edition, Politico's Publishing, London, 223-239.

[33] Richardson, C.J. and Hussain, N.A. (2006) Restoring the Garden of Eden: An Ecological Assessment of the Marshes of Iraq. Bioscience, 56, 477-489. https://doi.org/10.1641/0006-3568(2006)56[477:RTGOEA]2.0.CO;2

[34] Gleick, P.H. (1993) Water and Conflict: Fresh Water Resources and International Security. International Security, 18, 79-112. https://doi.org/10.2307/2539033

[35] Coast, E. (2003) Demography of the Marsh Arabs. In: Nicholson, E. and Clark, P., Eds., The Iraqi Marshlands: A Human and Environmental Study, 2nd Edition, Politico's Publishing, London, 19-35.

[36] Sultan, M.A., Maz Attyia, M.N., Al Maliki, A.A., Al-Ansari, N., et al. (2019) Change Detection and Impact of Climate Changes to Iraqi Southern Marshes Using Landsat 2 MSS, Landsat 8 OLI and Sentinel 2 MSI Data and GIS Applications. Applied Sciences, 9, 1-14. https://doi.org/10.3390/app9102016

[37] Hasab, H.A., Jawad, H.A., Dibs, H., Hussain, H.M. and Al-Ansari, N. (2020) Evaluation of Water Quality Parameters in Marshes Zone Southern of Iraq Based on Remote Sensing and GIS Techniques. Water, Air, \& Soil Pollution, 231, Article No. 183. https://doi.org/10.1007/s11270-020-04531-z

[38] Sluglett, P. (2003) The International Context of Iraq from 1980 to the Present. In: Nicholson, E. and Clark, P., Eds., The Ira New Eden Master Plan for the Integrated Water Resources Management in the Marshland Area, Politico's Publishing, London, 17-52.

[39] Dempster, C. (2007) Resilience of Social-Ecological Systems (SESs): A Case Study of Water Management in the Iraqi Marshlands.

[40] Al-Ansari, N.A. (2016) Hydro-Politics of the Tigris and Euphrates Basins. Engineering, 8, 140-172. https://doi.org/10.4236/eng.2016.83015

[41] Al-Ansari, N.A. and Knutsson, S. (2011) Toward Prudent Management of Water Resources in Iraq. Journal of Advanced Science and Engineering Research, 1, 53-67.

[42] Al-Ansari, N. (2019) Water Politics of the Tigris and Euphrates Basins. Middle East Water Forum Publications. (In Arabic) https://www.mewf.de

[43] Al-Ansari, N. (2019) Hydro Geopolitics of the Tigris and Euphrates. In: Mustafa, Y., Sadkhan, S., Zebari, S. and Jacksi, K., Eds., Recent Researches in Earth and Environmental Sciences, Part of the Springer Proceedings in Earth and Environmental Sciences Book Series (SPEES), Springer, Berlin, 35-70. https://doi.org/10.1007/978-3-030-18641-8_4

[44] Al-Ansari, N., Adamo, N., Sissakian, V., Knutsson, S. and Laue, J. (2018) Geopolitics of the Tigris and Euphrates Basins. Journal of Earth Sciences and Geotechnical Engineering, 8, 187-222.

[45] Al-Ansari, N., Adamo, N., Sissakian, V., Knutsson, S. and Laue, J. (2018) Water Resources of the Tigris River Catchment. Journal of Earth Sciences and Geotechnical Engineering, 8, 21-42.

[46] Al-Ansari, N., Al Jawad, S., Adamo, N., Sissakian, V., Laue, J. and Knutsson, S. (2018) Water Quality within the Tigris and Euphrates Catchments. Journal of Earth Sciences and Geotechnical Engineering, 8, 95-121.

[47] Al-Ansari, N.A. (2013) Management of Water Resources in Iraq: Perspectives and 
Prognoses. Engineering, 5, 667-684. https://doi.org/10.4236/eng.2013.58080

[48] Adamo, N., Al-Ansari, N., Sissakian, V., Knutsson, S. and Laue, J. (2018) The Future of the Tigris and Euphrates Water Resources in View of Climate Change. Journal of Earth Sciences and Geotechnical Engineering, 8, 59-74.

[49] Adamo, N., Al-Ansari, N., Sissakian, V., Knutsson, S. and Laue, J. (2018) Climate Change: The Uncertain Future of Tigris River Tributaries' Basins. Journal of Earth Sciences and Geotechnical Engineering, 8, 75-93.

[50] Issa, I.E., Al-Ansari, N.A., Sherwany, G. and Knutsson, S. (2014) Expected Future of Water Resources within Tigris-Euphrates Rivers Basin, Iraq. Journal of Water Resource and Protection, 6, 421-432. https://doi.org/10.4236/jwarp.2014.65042

[51] Abbas, N., Al-Ansari, N., Wasimi, S. and Al-Rawabdeh, A.M. (2019) Flow Variation of the Major Tributaries of Tigris River Due to Climate Change. Engineering, 11, 437-442. https://doi.org/10.4236/eng.2019.118031

[52] Abbas, N., Wasim, S.A. and Al-Ansari, N.A. (2016) Assessment of Climate Change Impacts on Water Resources of Lesser Zab, I, Kurdistan, Iraq. Journal of Engineering, 8, 697-715. https://doi.org/10.4236/eng.2016.810064

[53] Abbas, N., Wasimi, S., Al-Ansari, N. and Nasrin, S. (2018) Recent Trends and Long-Range Forecasts of Water Resources of Northeast Iraq and Climate Change Adaptation Measures. Journal of Water, Special Issue Water Resources Management Strategy under Globe Change, 10, 2-19. https://doi.org/10.3390/w10111562

[54] Abbas, N., Wasimi, N. and Al-Ansari, N. (2019) Impacts of Climate Change on Stream Flow of Major Four Tributaries of Tigris. World Forum on Climate Change, Glasgow, 19-21 June 2019, 26-45.

[55] Abbas, N., Wasimi, S.A. and Al-Ansari, N.A. (2017) Impacts of Climate Change on Water Resources of Greater Zab and Lesser Zab Basins, Iraq, Using Soil and Water Assessment Tool Model. International Journal of Environmental, Chemical, Ecological, Geological and Geophysical Engineering, 11, 808-814. https://doi.org/10.17265/1934-7359/2016.12.009

[56] Abbas, N., Wasim, S.A. and Al-Ansari, N.A. (2016) Impacts of Climate Change on Water Resources in Diyala River Basin, Iraq. Journal of Civil Engineering and Architecture, 10, 1059-1074. https://doi.org/10.17265/1934-7359/2016.09.009

[57] Abbas, N., Wasim, S.A. and Al-Ansari, N.A. (2016) Assessment of Climate Change Impacts on Water Resources of Khabour in Kurdistan, Iraq. Journal of Environmental Hydrology, 24, 1-21.

[58] Abbas, N., Wasim, S.A. and Al-Ansari, N.A. (2016) Assessment of Climate Change Impacts on Water Resources of Al-Adhaim, Iraq. Journal of Engineering, 8, 716-732. https://doi.org/10.4236/eng.2016.810065

[59] Abbas, N., Wasimi, S. and Al-Ansari, N.A. (2016) Climate Change Impacts on Water Resources of Greater Zab River, Iraq. Journal of Civil Engineering and Architecture, 10, 1384-1402. https://doi.org/10.17265/1934-7359/2016.12.009

[60] Al-Ansari, N.A., Abdulatif, M., Zakaria, S., Mustafa, Y. and Knutsson, S. (2015) Future Prospects for Macro Rainwater Harvesting (RWH) Technique in Northeast Iraq. International Symposium on Energy Challenges and Mechanics, Aberdeen, 8-10 July 2015, 124-139.

[61] Osman, Y., Abdellatif, M., Al-Ansari, N.A., Knutsson, S. and Aljawad, S.B. (2017) Climate Change and Future Precipitation in Arid Environment of Middle East: Case study of Iraq. Journal of Environmental Hydrology, 25, 1-18.

[62] Osman, Y., Al-Ansari, N.A., Abdellatif, M., Aljawad, S.B. and Knutsson, S. (2014) 
Expected Future Precipitation in Central Iraq Using LARS-WG Stochastic Weather Generator. Engineering, 6, 948-959. https://doi.org/10.4236/eng.2014.613086

[63] Osman, Y., Al-Ansari, N.A. and Abdellatif, M. (2019) Climate Change Model as a Decision Support Tool for Water Resources Management: A Case Study of Greater Zab River. Journal of Water and Climate Change, 10, 197-209.

https://doi.org/10.2166/wcc.2017.083

[64] GAP (2006) South-Eastern Anatolia Project: Latest Situation. http://www.gap.gov.tr/English/Genel/sdurum.pdf

[65] Olcay Unver, I.H. (1997) Southeastern Anatolia Project (GAP). International Journal of Water Resources Development, 13, 453-484.

http://www.informaworld.com/smpp/title $\sim \mathrm{db}=\mathrm{all} \sim$ content $=\mathrm{t} 713426247 \sim \mathrm{tab}=\mathrm{issues}$ list $\sim$ branches $=13$-v13 https://doi.org/10.1080/07900629749575

[66] MacQuarrie, P. (2004) Water Security in the Middle East, Growing Conflict over Development in the Euphrates-Tigris Basin. M.Phil Thesis, Trinity College, Dublin. http://www.transboundarywaters.orst.edu/publications/abst_docs/related_research/ MacQuarrie2004.pdf 